\title{
Monitoring Methods the Properties and Structure of Grey Iron Castings
}

Iva Nova, Jiri Machuta

Faculty of Mechanical Engineering, Technical University of Liberec, Studentska 2, 46117 Liberec. Czech Republic. Email:iva.nova@tul.cz,jiri.machuta@tul.cz

Flake graphite cast irons are very used construction materials, which are characterized by good sliding and damping properties. Graphite and character matrix affects the properties of cast iron. It is also important to the size distribution of the graphite. Compressive strength graphite cast iron with lamellar graphite is very good, is 3 to 4 times greater than the tensile strength. The various types of cast iron with lamellar graphite is possible only in the tensile strength. Flake graphite cast iron are widely used in mass production where they use their good casting properties. With sophisticated sand moulds can produce a very complex shape castings with excellent mechanical properties and relatively low production costs. For this reason, cast iron with lamellar graphite are constantly used in the automotive industry for blocks, heads, engines, brake drums and discs, insertion loss cylinders, piston rings. At our department of Engineering Technology, Technical university of Liberec (Czech Republic - Europe) has long been focused on prediction methods of production quality castings for the automotive industry.

Keywords: Grey cast iron, Structure, Prediction quality, Mechanical properties, Simulation

\section{Acknowledgement}

Project supported by: „Support of the creation of excellent research and development teams at the Technical University of Liberec", registration number: No. CZ.1.07/2.3.00/30.0065.

\section{References}

[1] MACKENZIE, J. T.: (1946). Brinell Hardness of Grey Cast Iron-Its Relation to Other Properties. Foundry, Vol. 74, No. 10, Oct., pp. 88-93.

[2] LA PLANCHE, H. (1949) Foundry Trade Journal, No. 16, p. 85.

[3] BOYLES, A. (1947) The Structure of Cast Iron, American Society for Metals, Metals Park.

[4] GIRSOVIC, N. G.: (1955). (Transfer Russian to Czech). SNTL Prague.

[5] PLACHÝ, J., OTÁHAL, V. (Cast iron I., II 1956). Jakostní litiny. (The quality cast irons). SNTL Prague, Czech, (in Czech).

[6] COLlaud, A. (1960) Giesserei, 47, Nu. 25, S. 719.

[7] Loper, C.R. (1999) Inoculation of Cast Iron, Summary of Current Understanding. AFS Transactions, Vol. 107, pp. 523 - 528.

[8] WERBIG, H. (2000) Gusseisen Mit Lamellengraphit: Eigenschaften Und Anwendung Düsseldorf: ZGV-Zentrale für Gußverwendung.

[9] SAPOZDNIKOV, S.A, ASTASHKEVICH, B.M. (2003) Structure and properties of iron piston ring manufactured by continuous cycling casting. Metal Science and Heat treatment. Vol. 45, No. 3-4.

[10] SKRBEK, B. Použití ultrazvuku k hodnocení jakosti litinových odlitků. (Use of ultrasound evaluation of iron casting quality). Slévárenství LIV, č. 9, pp. 334 -339 (in Czech).

[11] Riposan, I., Chisamera, M., Stan, S., Skaland, T. (2005) A new Approach to Graphite Nucleation Mechanism in Grey Irons. AFS Cast Iron Inoculation Conference, pp. $31-41$.

[12] SJÖGREN, T. (2007) Influence of the graphite fase on elastic and Plastic deformation behaviour of cast Irons. [Dissertaion in science and technology]. Linköping University, Sweden.

[13] ANDRŠOVÁ, Z., SKRBEK, B. (2012) The of magnetic and ultrasonic structuroscopy for inspection of ADI/AGI castings. Manufacturing Technology, December, Vol. 12, No 13, pp. 93 - 97. ISSN 1213-2489.

[14] HORÁČEK, J., NOVÁ, I. (2011) Simulační výpočty tuhnutí a chladnutí odlitků z litany. (Simulation calculations of solidification and cooling iron castings). Strojírenská technologie. December, Vol. XVI,No 6.pp. 12-17. ISSN 1211-4162. 